OPEN ACCESS

Edited by: James Cotner,

University of Minnesota, United States

Reviewed by: Joanna Dorota Mankiewicz-Boczek, University of Łódź, Poland Jinjun Kan,

Stroud Water Research Center, United States

${ }^{*}$ Correspondence: Antonio Castellano-Hinojosa ach@ugr.es

Specialty section: This article was submitted to

Aquatic Microbiology,

a section of the journa

Frontiers in Microbiology

Received: 07 April 2017 Accepted: 19 September 2017 Published: 06 October 2017

Citation:

Castellano-Hinojosa A Correa-Galeote $D$, Carrillo $P$, Bedmar EJ and Medina-Sánchez JM (2017) Denitrification and Biodiversity of Denitrifiers in a High-Mountain Mediterranean Lake.

Front. Microbiol. 8:1911 doi: 10.3389/fmicb.2017.01911

\section{Denitrification and Biodiversity of Denitrifiers in a High-Mountain Mediterranean Lake}

\author{
Antonio Castellano-Hinojosa ${ }^{1,2 *}$, David Correa-Galeote ${ }^{1}$, Presentación Carrillo ${ }^{2,3}$, \\ Eulogio J. Bedmar ${ }^{1}$ and Juan M. Medina-Sánchez ${ }^{2,3}$
}

\begin{abstract}
'Departamento de Microbiología del Suelo y Sistemas Simbióticos, Estación Experimental del Zaidín, Consejo Superior de Investigaciones Cientificas, Granada, Spain, ${ }^{2}$ Instituto Universitario de Investigación del Agua, Universidad de Granada, Granada, Spain, ${ }^{3}$ Departamento de Ecología, Facultad de Ciencias, Universidad de Granada, Granada, Spain
\end{abstract}

Wet deposition of reactive nitrogen ( $\mathrm{Nr}$ ) species is considered a main factor contributing to $\mathrm{N}$ inputs, of which nitrate $\left(\mathrm{NO}_{3}^{-}\right)$is usually the major component in high-mountain lakes. The microbial group of denitrifiers are largely responsible for reduction of nitrate to molecular dinitrogen $\left(\mathrm{N}_{2}\right)$ in terrestrial and aquatic ecosystems, but the role of denitrification in removal of contaminant nitrates in high-mountain lakes is not well understood. We have used the oligotrophic, high-altitude La Caldera lake in the Sierra Nevada range (Spain) as a model to study the role of denitrification in nitrate removal. Dissolved inorganic $\mathrm{Nr}$ concentration in the water column of la Caldera, mainly nitrate, decreased over the ice-free season which was not associated with growth of microbial plankton or variations in the ultraviolet radiation. Denitrification activity, estimated as nitrous oxide $\left(\mathrm{N}_{2} \mathrm{O}\right)$ production, was measured in the water column and in sediments of the lake, and had maximal values in the month of August. Relative abundance of denitrifying bacteria in sediments was studied by quantitative polymerase chain reaction of the $16 S$ rRNA and the two phylogenetically distinct clades nos $Z$ I and nosZII genes encoding nitrous oxide reductases. Diversity of denitrifiers in sediments was assessed using a culture-dependent approach and after the construction of clone libraries employing the nosZI gene as a molecular marker. In addition to genera Polymorphum, Paracoccus, Azospirillum, Pseudomonas, Hyphomicrobium, Thauera, and Methylophaga, which were present in the clone libraries, Arthrobacter, Burkholderia, and Rhizobium were also detected in culture media that were not found in the clone libraries. Analysis of biological activities involved in the $\mathrm{C}, \mathrm{N}, \mathrm{P}$, and $\mathrm{S}$ cycles from sediments revealed that nitrate was not a limiting nutrient in the lake, allowed $\mathrm{N}_{2} \mathrm{O}$ production and determined denitrifiers' community structure. All these results indicate that denitrification could be a major biochemical process responsible for the $\mathrm{N}$ losses that occur in La Caldera lake.

Keywords: high-mountain lake, nitrate, nitrous oxide, water column, sediments, $16 \mathrm{~S}$ rRNA gene, nosZ gene, biodiversity 


\section{INTRODUCTION}

In the context of global alterations of the biogeochemical cycles, inland aquatic ecosystems are considered as true sentinels of change due to its high connectivity with terrestrial ecosystems (Williamson et al., 2009). Among them, high-mountain lakes located in remote areas at high altitude, with small catchment areas and small volume of water, are strongly influenced by processes of atmospheric transport (Brahney et al., 2015; Cabrerizo et al., 2017). These features, and the fact that their food webs are usually simple, but with complex interactions (Carrillo et al., 2006), make them excellent witnesses of global change and suitable model ecosystems to quantify basic processes related to the functioning and alterations of biogeochemical cycles (Catalán et al., 2006; Medina-Sánchez et al., 2013; Durán et al., 2016).

That of $\mathrm{N}$ is one of the biogeochemical cycles under greater alteration currently at global scale (Galloway et al., 2008). This acceleration is due to the increase in the availability of reactive nitrogen $(\mathrm{Nr})$ species as a result of human activity, including industrially produced fertilizer, combustion of fossil fuels, transportation, biomass and agricultural burning, intensification of biological $\mathrm{N}_{2}$ fixation by agriculture, etc. (Fowler et al., 2013; Hertel et al., 2014). Due to alterations of the natural $\mathrm{N}$ cycle, human health, ecosystem integrity, resilience, and biodiversity are already suffering serious and potentially irreversible effects (Erisman et al., 2011, 2013; Shibata et al., 2015). The long-term consequences are yet unknown, but the current human impact on this cycle has exceeded the operating limits considered safe (Rockström et al., 2009; Steffen et al., 2015).

Within the $\mathrm{N}$ cycle, dissimilatory reduction of nitrate to ammonium, chemoautotrophic denitrification via sulfur or iron oxidation, anammox and, mainly denitrification are the only known biological processes involved in removal of $\mathrm{Nr}$ species in the biosphere (Burgin and Hamilton, 2007; Galloway et al., 2013; Erisman et al., 2015). During denitrification, nitrate $\left(\mathrm{NO}_{3}^{-}\right)$ can be reduced to $\mathrm{N}_{2}$ via the formation of nitrite $\left(\mathrm{NO}_{2}{ }^{-}\right)$, nitric oxide (NO) and nitrous oxide $\left(\mathrm{N}_{2} \mathrm{O}\right)$ under oxygenlimiting conditions. Those reactions are carried out by the nitrate- (Nar/Nap), nitrite- (nirK/NirS), NO- (cNor/qNor), and nitrous oxide-reductase (NosZI and NosZII) enzymes encoded by the narG/napA, nirK/nirS, c-norC/q-norC, and nos Z clades I (nosZI) and II (nosZII) genes, respectively (Zumft, 1997; van Spanning et al., 2007; Richardson, 2011; Bedmar et al., 2013). Many denitrifiers do not have, or do not express, the complete set of enzymes required for denitrification, which, in turn, may result not only in nitrite formation, but also in the release into the atmosphere of $\mathrm{NO}$ and $\mathrm{N}_{2} \mathrm{O}$, two potent greenhouse gases that are involved in global climatic change, formation of acid rain and destruction of the ozone layer (Ravishankara et al., 2009; IPCC, 2013; Erisman et al., 2015).

Flow of $\mathrm{Nr}$ species through the atmosphere causes their deposition on aquatic ecosystems, including those in remote areas such as high-mountain lakes (Catalán, 1992; Catalán et al., 1993; Elser et al., 2009a,b; Ga̧siorowski and Sienkiewicz, 2013). Through validated chemical transport models, high wet depositions of $\mathrm{Nr}$ have been reported in North and Northeastern Spain, decreasing along the NE-SW axis of the Iberian Peninsula (García-Gómez et al., 2014). In Sierra Nevada mountains (southern Spain), inputs of $\mathrm{N}$ are mainly related to wet deposition, which are not related to Saharan dust export toward the Mediterranean region (Morales-Baquero et al., 2006; Morales-Baquero and Pérez-Martínez, 2016). Long-term observations in the high-mountain lake La Caldera within the Sierra Nevada range shows that, despite $\mathrm{Nr}$ depositions, an inter-annually seasonal trend of decreasing dissolved inorganic nitrogen (DIN) can be established, with nitrate $\left(\mathrm{NO}_{3}^{-}\right)$as the predominant inorganic form (Carrillo et al., 1996; MedinaSánchez et al., 1999; Delgado-Molina et al., 2009). Decreases in DIN, however, were not associated with the dynamics of total biomass of La Caldera, so that reasons for $\mathrm{N}$ losses remain elusive.

Incubation experiments with ${ }^{15} \mathrm{~N}$-nitrite revealed $\mathrm{N}$ loss occurring in the chemocline through denitrification in the highmountain, meromictic Cadagno lake (Switzerland) (Halm et al., 2009). Also, a growing gradient of DIN toward the hypolimnetic redox transition zone indicated the existence of sulfidedependent denitrifiers in the water column of the meromictic south-alpine Lugano lake (Wenk et al., 2013). Moreover, a high bacterial diversity, including anaerobic microorganisms and the presence of denitrifying bacteria in epilithic biofilms was shown in oligotrophic mountain lakes (Bartrons et al., 2012), despite these microhabitats had been considered unsuitable for denitrification (Vila-Costa et al., 2014). Previous studies have reported the dominance of alpha and beta proteobacteria in the water column of La Caldera lake (Reboleiro-Rivas et al., 2013), but denitrifiers have not been determined in this ecosystem, so that whether or not denitrification is involved in nitrate removal in the oligotrophic lake of La Caldera is not known. Accordingly, the main goal of this study was to analyze denitrification activity in the water column and in sediments that could be responsible for the seasonal $\mathrm{N}$ loss pattern found in La Caldera lake over an interannual temporal scale. For this purpose denitrification activity was examined as $\mathrm{N}_{2} \mathrm{O}$ production in the water column and sediment samples. Abundance of denitrifiers was estimated by quantitative polymerase chain reaction (qPCR) and bacterial identification was made after construction of clone libraries with nos $Z$ genes. Finally, abiotic factors involved in control of denitrification activity were also determined.

\section{MATERIALS AND METHODS}

\section{Study Site}

La Caldera is an oligotrophic, high-mountain lake located on the southern slope of Sierra Nevada range (Southeast Spain), at 3050 masl, very close to the level of summits $\left(36^{\circ} 55^{\prime}-37^{\circ} 15^{\prime} \mathrm{N}\right.$, $\left.2^{\circ} 31^{\prime}-3^{\circ} 40^{\prime} \mathrm{W}\right)$. With a catchment area of $\sim 1.46 \mathrm{~km}^{2}$, it stands at a glacial cirque of rocky siliceous nature (shales, quartzites), tectonically belonging to the Mulhacén mantle of the NevadoFilábride complex of Betic ranges. The lake has an area of $\sim 0.02 \mathrm{~km}^{2}$, an average depth of $4.3 \mathrm{~m}$, and lacks visible tributaries or effluents and littoral vegetation. 


\section{Sampling, Physicochemical and Biological Variables of the Water Column}

Based on a consistent seasonal pattern at interannual longterm scale of nitrate dynamics and planktonic community development along the ice-free period (Carrillo et al., 1996, 2008; Villar-Argaiz et al., 2001; Delgado-Molina et al., 2009), sampling was performed during the ice-free period on June 9, August 1 , and October 13, 2015. At the maximum depth point of the lake, temperature, dissolved oxygen (DO), conductivity, total dissolved solids (TDS), and $\mathrm{pH}$ were measured in situ along the water column using a multiparameter probe (TuroWater Quality Analysis T-611, Sandy Bay, TAS, Australia). Vertical profiles of solar radiation in the water column were determined at noon with a BIC compact four-channel radiometer (Biospherical Instruments, CA, United States) equipped with three channels in the ultraviolet region (UVR) of the spectra $(305,320$, and $380 \mathrm{~nm}$ ) and one broadband channel for photosynthetic active radiation (PAR; 400-700 nm). Diffuse attenuation coefficients for downward irradiance $\left(K_{d}\right)$ were calculated from the slope of the linear regression of natural logarithm of downwelling irradiance vs. depth for each wavelength range considered. A large sample size (pairs irradiance-depth data, $n>100$ ) was used and a good fit $\left(R^{2}>0.90\right)$ was found for all regressions. Lake water samples were collected with an acidcleaned horizontal $6 \mathrm{~L}$ van Dorn sampler at the deepest central station from three to four depths depending on the water column size and date $(0.5 \mathrm{~m}$ below surface, $0.5 \mathrm{~m}$ above bottom, and two intermediate depths, Table 1). Total phosphorus (TP), total dissolved phosphorus (TDP), total nitrogen (TN), soluble reactive phosphorous (SRP), nitrate $\left(\mathrm{NO}_{3}^{-}\right)$, dissolved organic carbon (DOC), and chlorophyll $a$ $(\mathrm{Chl} a)$ in the water samples were analyzed as described previously (Carrillo et al., 2015) following standard methods (APHA, 2005). Bacterial abundance in the water column was quantified by the flow cytometry technique (FACSCanto, Becton Dickinson Biosciences) as described in Dorado-García et al. (2014). Microbial plankton biomass (MPB) in La
Caldera lake is composed mainly of nanoplanktonic algae and heterotrophic bacteria, because other components of the microbial loop such as ciliates, heterotrophic nanoflagellates, and autotrophic picoplankton are not detected (Dorado-García et al., 2014; Cabrerizo et al., 2017). Hence, MBP was estimated as: $\mathrm{MPB}=\mathrm{AB}+\mathrm{BB}$, where $\mathrm{AB}$ is the algal biomass calculated by multiplying a C:Chl $a$ ratio of 7.48 (obtained from Carrillo et al., 2015) by the measured $\mathrm{Chl} a$; $\mathrm{BB}$ is the bacterial biomass calculated as the product of the carbon content per bacterial cell (obtained from Carrillo et al., 2015) by the measured bacterial abundance.

Sediment samples were taken from the top layer $(0-10 \mathrm{~cm})$ at four sampling sites (Supplementary Figure S1). They were kept refrigerated, transported to the laboratory and maintained at $-80^{\circ} \mathrm{C}$ until use.

\section{Enzymatic Analysis}

Raw sediment and water column samples were used to analyze enzymatic activities (EA) related to $\mathrm{C}, \mathrm{N}, \mathrm{P}$, and $\mathrm{S}$ biogeochemical cycles. Sediment moisture was determined gravimetrically by oven-drying the samples at $105^{\circ} \mathrm{C}$ for $24 \mathrm{~h}$. Dehydrogenase was used to estimate overall microbial activity, $\beta$-glucosidase (GLU) as the enzyme that catalyses the hydrolysis of disaccharides (C cycle), urease (UR) which catalyses the hydrolysis of urea to $\mathrm{CO}_{2}$ and $\mathrm{NH}_{3}(\mathrm{~N}$ cycle), acid phosphatase (AP) for estimation of the enzymes responsible for the hydrolysis of phosphate esters ( $\mathrm{P}$ cycle), and arylsulphatase (AS) as a measure of the enzymes catalyzing the hydrolysis of organic sulfate esters (S cycle). Dehydrogenase was assayed according to García et al. (1997), GLU, AP, and AS were estimated according to Tabatabai (1982), and UR activity was determined as indicated by Kandeler and Gerber (1988). Briefly, these techniques were based on a controlled incubation of the samples after adding the initial substrate (INT, 2-p-iodophenyl-3-p-nitrophenyl5-tetrazolium for dehydrogenase; $p \mathrm{NG}, 4$-nitrophenyl- $\beta$-Dglucopyranoside for GLU; urea for UR activity; $p N P P$, 4nitrophenyl phosphate for AP; and pNPS, $p$-nitrophenyl sulfate

TABLE 1 | Physicochemical and biological properties of the water column from La Caldera lake (Sierra Nevada, Spain).

\begin{tabular}{|c|c|c|c|c|c|c|c|c|}
\hline $\begin{array}{l}\text { Sampling } \\
\text { month }\end{array}$ & $\begin{array}{c}\text { Depth } \\
\text { (m) }\end{array}$ & $\begin{array}{c}\text { TP } \\
\left(\mu \mathrm{g} \mathrm{P} \mathrm{L}^{-1}\right)\end{array}$ & $\begin{array}{c}\text { TDP } \\
\left(\mu \mathrm{g} \mathrm{P} \mathrm{L}^{-1}\right)\end{array}$ & $\begin{array}{c}\text { SRP } \\
\left(\mu \mathrm{g} \mathrm{P} \mathrm{L}^{-1}\right)\end{array}$ & $\begin{array}{c}\text { TN } \\
\left(\mathrm{mg} \mathrm{N} \mathrm{L}^{-1}\right)\end{array}$ & $\begin{array}{c}\mathrm{NO}_{3}^{-} \\
\left(\mathrm{mg} \mathrm{N} \mathrm{L}^{-1}\right)\end{array}$ & $\begin{array}{c}\text { DOC } \\
\left(\mathrm{mg} \mathrm{L}^{-1}\right)\end{array}$ & $\begin{array}{c}\text { MPB } \\
\left(\mu \mathrm{g} \mathrm{C} \mathrm{L}^{-1}\right)\end{array}$ \\
\hline \multirow[t]{4}{*}{ June } & 0.5 & 2.4 & 1.2 & 0.12 & 0.30 & 0.32 & 0.40 & 21.34 \\
\hline & 2 & 2.6 & 1.6 & 0.14 & 0.35 & 0.31 & 0.42 & 21.10 \\
\hline & 4 & 3.1 & 1.8 & 0.23 & 0.50 & 0.32 & 0.43 & 21.19 \\
\hline & 6 & 3.1 & 4.1 & 0.20 & 0.46 & 0.38 & 0.50 & 24.71 \\
\hline \multirow[t]{4}{*}{ August } & 0.5 & 4.2 & 1.2 & 0.60 & 0.22 & 0.11 & 0.41 & 45.09 \\
\hline & 2 & 5.7 & 2.8 & 0.15 & 0.23 & 0.10 & 0.37 & 31.84 \\
\hline & 4 & 5.8 & 2.8 & 0.14 & 0.25 & 0.09 & 0.32 & 42.63 \\
\hline & 6 & 5.8 & 2.3 & 0.54 & 0.13 & 0.12 & 0.31 & 43.00 \\
\hline \multirow[t]{3}{*}{ October } & 0.5 & 4.5 & 1.9 & 0.32 & 0.10 & 0.06 & 0.95 & 19.13 \\
\hline & 1.5 & 6.2 & 2.5 & 0.32 & 0.12 & 0.06 & 0.87 & 19.30 \\
\hline & 3 & 7.0 & 2.8 & 1.17 & 0.15 & 0.07 & 0.61 & 19.70 \\
\hline
\end{tabular}

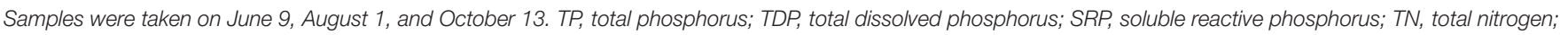
$\mathrm{NO}_{3}^{-}$, nitrate content; DOC, dissolved organic carbon; MPB, microbial plankton biomass. 
for AS, respectively) and measuring the ending product of each enzyme reaction colorimetrically (INTF, iodonitrotetrazolium formazan for dehydrogenase; $p \mathrm{NP}, p$-nitrophenol for GLU, AP, and AS; and $\mathrm{NH}_{4}{ }^{+}$for UR activity).

EA ratios (GLU:AP, GLU:UR, GLU:AS, UR:AP, UR:AS) were calculated as indicators of nutrient-ratio limitations (C:P, C:N, $\mathrm{C}: \mathrm{S}, \mathrm{N} ; \mathrm{P}, \mathrm{N}: \mathrm{S}$, respectively) according to previous studies on EA (Sinsabaugh et al., 2009; Sinsabaugh and Follstad-Shah, 2012; Velasco-Ayuso et al., 2017). Propagation errors were used to calculate the variance of each EA ratio.

\section{Determination of $\mathrm{N}_{\mathbf{2}} \mathrm{O}$ and $\mathrm{N}_{\mathbf{2}}$}

$\mathrm{N}_{2} \mathrm{O}$ production by the water column $\left(\mathrm{N}_{2} \mathrm{O}_{W}\right)$ and sediment $\left(\mathrm{N}_{2} \mathrm{O}_{S}\right)$ samples was assayed as indicated earlier (Tortosa et al., 2011). Briefly, $25 \mathrm{~g}$ of sediments (covered with a $2 \mathrm{~cm}$ layer of water from the lake) or $25 \mathrm{~mL}$ of water from the water columns were placed in $125 \mathrm{~mL}$ glass bottles and closed with serum rubber caps to allow injection and withdrawal of gas samples. Then, $10 \%$ of the internal atmosphere of the flasks was removed and acetylene was injected to inhibit nitrous oxide reductase activity (Yoshinari and Knowles, 1976). After incubation at temperatures measured in the sediment and water column, samples $(0.5 \mathrm{~mL})$ were withdrawn from the headspace of the flasks and injected into an HP 4890D gas chromatograph equipped with an electron capture detector and a Porapak Q 80/100 mesh packed column. $\mathrm{N}_{2}$ was the carrier gas at $28 \mathrm{~mL} \mathrm{~min}{ }^{-1}$ flow rate and the injector, column and detector temperatures were 125,60 , and $375^{\circ} \mathrm{C}$, respectively. Denitrification activity was calculated from the $\mathrm{N}_{2} \mathrm{O}$ increases during incubation using the Bunsen coefficient for the $\mathrm{N}_{2} \mathrm{O}$ dissolved in water. In parallel experiments, $\mathrm{N}_{2} \mathrm{O}$ production was also determined after incubation of the samples without acetylene. $\mathrm{N}_{2}$ production was estimated as the difference between $\mathrm{N}_{2} \mathrm{O}$ emission with and without acetylene. $\mathrm{N}_{2} \mathrm{O}$ concentrations were calculated using $2 \%(\mathrm{v} / \mathrm{v}) \mathrm{N}_{2} \mathrm{O}$ standard (Air Liquid).

\section{DNA Extraction from Sediments and Quantification of N Cycle-Associated Microbial Community}

DNA was extracted from thawed $250 \mathrm{mg}$ sediment samples using the PowerSoil ${ }^{\circledR}$ DNA isolation kit according to the manufacturer's instructions. Quality and size of soil DNA were checked by electrophoresis on $1 \%$ agarose. DNA was also quantified by spectrophotometry at $260 \mathrm{~nm}$ using a BioPhotometer (Eppendorf, Hamburg, Germany). The size of the denitrifier community was estimated by qPCR of nos $Z$ gene clades I (Henry et al., 2006) and II (Jones et al., 2012) fragments as described earlier (Correa-Galeote et al., 2013). Primers were used to amplify a $267 \mathrm{bp}$ fragment of nos $Z$ within clade I and 720 bp fragment of nos $Z$ within clade II. The total bacterial community was quantified using $16 \mathrm{~S}$ rRNA gene as molecular marker as described by López-Gutiérrez et al. (2004). Reactions were carried out in an ABI Prism 7900 Sequence Detection System (Applied Biosystems). Quantification was based on the fluorescence intensity of the SYBR Green dye during amplification. qPCR assays were performed in triplicate for each of the four samples taken in each sampling date. Standard curves were obtained using serial dilutions of linearized plasmids containing cloned nosZ clades I and II and 16S rRNA genes amplified from bacterial strains. PCR efficiency for the different assays ranged between 90 and 99\%. No template controls gave null or negligible values. Presence of PCR inhibitors in DNA extracted from soil was estimated by (i) diluting soil DNA extract and (ii) mixing a known amount of standard DNA to soil DNA extract prior to qPCR. In all cases, inhibition was not detected. Methodological evaluation of the real-time PCR assays showed a good reproducibility of $95.0 \pm 12 \%$ between two runs.

\section{Clone Libraries Construction and DNA Sequencing}

nosZ genes amplicons of clades I and II obtained during PCR assays for libraries construction were purified using the QIAquick PCR purification kit (Qiagen, Germany) and cloned using the pGEM-T Easy cloning kit according to the manufacturer's instructions (Promega, United States). The recombinant Escherichia coli JM109 cells were inoculated onto solid Luria Bertani medium (Miller, 1972) containing ampicillin and X-Gal (5-bromo-4-chloro-3-indolyl- $\beta$-D-galactopyranoside), and grown overnight at $37^{\circ} \mathrm{C}$. White colonies were screened by PCR using the vector primers Sp6 and T7 (Invitrogen). Purity of amplified products was checked by observation of a unique band of the expected size in a $1 \%$ agarose gel stained with GelRed as indicated by the manufacturer's (Biotium Inc., United States). Nucleotide sequences of clones containing inserts of the expected size were determined by sequencing with the vector primer Sp6 and the BigDye terminator cycle kit v3.1 (Applied Biosystems, United States) according to the manufacturer's instructions, followed by electrophoresis on an ABI 3100 genetic analyzer (Applied Biosystems, United States) at the sequencing facilities of Estación Experimental del Zaidín, CSIC, Granada, Spain. Three clone libraries, JCL, ACL, and OCL, were obtained that contained nos $Z$ genes from sediments of La Caldera lake taken in June, August, and October, respectively.

\section{Phylogenetic Analysis and Diversity Indexes}

The DNA sequences of nos $Z$ gene fragments were aligned by using the ClustalW program available in the Geneious software package (version 6.0.3, Biomatters, New Zealand). Vector sequence was removed and discrepancies in alignment verified manually. The obtained sequences were compared against database sequences using the BLASTN program in Geneious and those showing similarity higher than $95 \%$ of those previously deposited in GenBank for nos $Z$ were selected as positives. A phylogenetic tree was constructed from a matrix of pairwise genetic distances by using the neighbor-joining method available in MEGA 7 (Kumar et al., 2015). Bootstrap analysis was based on 1000 resamplings. The Good's coverage values and the Shannon-Wiener and Simpson indexes were calculated using PAST software (v3.14). 


\section{Isolation of Denitrifying Bacteria from Sediments and Culture Conditions}

For each sampling time, sediment samples $(250 \mathrm{mg})$ were placed in microtubes containing $1 \mathrm{~mL}$ sterile saline solution, shaken in a vortex for $1 \mathrm{~min}$, and centrifuged at $6000 \mathrm{rpm}$ for $1 \mathrm{~min}$ in a microfuge. Then, $1 \mathrm{~mL}$ aliquots of the supernatant were taken and 1:100, 1:250, and 1:500 dilutions $(\mathrm{v} / \mathrm{v})$ were used to inoculate Petri dishes containing either solid G2M11, G3M12, or G4M3 media (Heylen et al., 2006), and placed inside anaerobic Anaerocult ${ }^{\circledR}$ jars (Millipore). The atmosphere inside the jar was made anoxic by using the commercial Anaerocult ${ }^{\circledR}$ system (Millipore). Cultures were incubated at $30^{\circ} \mathrm{C}$ until the appearance of colony forming units (CFUs). They were further selected by microscopic observation with a microscope Nikon CFI60 so that they represented all the different colony types appeared on the plates. Tryptone soya agar medium was used for routine bacterial growth.

\section{DNA Extraction and PCR Amplification of $16 S$ rRNA Gene from Bacterial Isolates}

Genomic DNA was isolated from bacterial cells as previously described (El Batanony et al., 2015). The quantity of DNA was determined by using a Nanodrop spectrophotometer (NanoDrop ND1000). To cluster the isolates, repetitive extragenic palindromic-PCR (REP-PCR) were performed using primers REPIR-I and REP2-I (de Bruijn, 1992). PCR amplifications of 16S rRNA gene fragments were carried out using the two opposing primers fD1 and rD1 (Herrera-Cervera et al., 1999). Amplification products were purified using the Qiagen PCR product purification system and subjected to cycle sequencing using the same primers as for PCR amplification, with ABI Prism dye chemistry and analyzed with a $3130 \mathrm{xl}$ automatic sequencer at the sequencing facilities of the Estación Experimental del Zaidín, CSIC, Granada, Spain. The 16S rRNA gene sequences were compared to those deposited in EzTaxon-e (Kim et al., 2012).

\section{Accession Numbers}

Sequences have been deposited in GenBank with accession numbers LT900218-LT900337.

\section{Statistical Analyses}

Significant differences among dates for each biological variable were tested by paired $t$-tests. To assess if the decrease in $\mathrm{NO}_{3}^{-}$ content over the ice-free period was related to $\mathrm{N}$-uptake due to the growth of the microbial plankton in water column, a regression analysis (MPB vs. $\mathrm{NO}_{3}^{-}$) was performed. The seasonal distribution patterns of the independent abiotic (temperature, $\mathrm{pH}, \mathrm{DO}, \mathrm{TN}, \mathrm{TP}, \mathrm{TDP}, \mathrm{SRP}, \mathrm{N}_{2} \mathrm{O}_{W}, \mathrm{~N}_{2} \mathrm{O}_{S}, \mathrm{NO}_{3}^{-}$, and DOC) and dependent biotic (total abundance of $16 \mathrm{~S}$ rRNA and nos $Z$ clades I and II genes) variables in lake La Caldera were studied by ordinations using non-parametric multidimensional scaling (NMDS), aided by the Primer software (PRIMER-E, vs. 6.0, Plymouth, United Kingdom). The data sets were transformed to $\log (x+1)$ and normalized. Sample-resemblance matrices were generated using the Bray-Curtis similarity coefficient. Values of stress level on the NMDS plots $<0.2$ indicate that they give an appropriate representation of the data distribution (Clarke and Warwick, 2001; Clarke et al., 2008). Spearman rank correlations of each variable were calculated and are represented in the plots as vectors that illustrate their directional influence and role in the ordination. To find potential relations between the biotic data and the environmental variables, a BIO-ENV analysis was performed. Global permutation tests (499 permutations, which is the maximum under the given number of permutations) were conducted to determine the highest value obtained which is called the BEST value. This value designates which subset of the abiotic variables best explains the distribution of the biotic data between samples. Stepwise multiple regression analysis was performed to assess the relative strength of the best abiotic variables selected in BEST for each biotic-dependent variable. Statistical analyses were done using the package Statgraphics (Statistical Graphics Corporation).

\section{RESULTS}

\section{Physicochemical Properties}

Main physicochemical and biological characteristics determined in the water column of La Caldera lake are shown in Table 1 and Supplementary Figure S2. Temperature of the water column exhibited a slight inverse stratification in June, and a slight thermal stratification in August and October. Except for October, the water column was nearly oxygen-saturated for all depths and sampling dates. Mean $\mathrm{pH}$ values for the water column were low in June (6.8), and reached values above neutrality in August (8.5) and October (8.03). TP and TDP values increased with depth and over the ice-free season. DOC values were $<1 \mathrm{mg} \mathrm{L}^{-1}$ and peaked in October $\left(0.81 \mathrm{mg} \mathrm{L}^{-1}\right)$. TN decreased over the ice-free season and, as expected, $\mathrm{NO}_{3}^{-}$concentration followed a similar pattern with values varying from $0.33 \mathrm{mg} \mathrm{N} \mathrm{L}^{-1}$ in June to $0.1 \mathrm{mg} \mathrm{N} \mathrm{L}^{-1}$ in August and $0.063 \mathrm{mg} \mathrm{N} \mathrm{L}^{-1}$ in October. The dynamic of $\mathrm{NO}_{3}^{-}$over the ice-free season did not explained the variance of MPB in the water column $\left(r^{2}=0.06, p>0.45\right)$ indicating that this seasonal change was not associated with growth of microbial plankton. Attenuation coefficients $\left(K_{d}\right)$ for UVR and PAR were lower in August than in June, whereas their highest values were found in October (Supplementary Figure S2). TDS increased hardly through the ice-free season and values of conductivity remained without measurable variations over the ice-free period (data not shown).

\section{Enzymatic Activities}

EA in sediments varied with the sampling times (Supplementary Table S1). Dehydrogenase, $\beta$-glucosidase, phosphatase, and arylsulfatase increased between June and August and decreased in October, with the lowest activity after thawing. In contrast, UR showed the lowest value in October. Despite repeated attempts to analyze EA in raw samples of the water column of the lake, obtained values were below the detection limits. The EA ratios varied from values below 1 (GLU:AP, UR:AP), not distinct from 1 (GLU:AS), to above 1 (GLU:UR, AS:UR), and this general pattern was kept or accentuated over the ice-free period (Figure 1). 


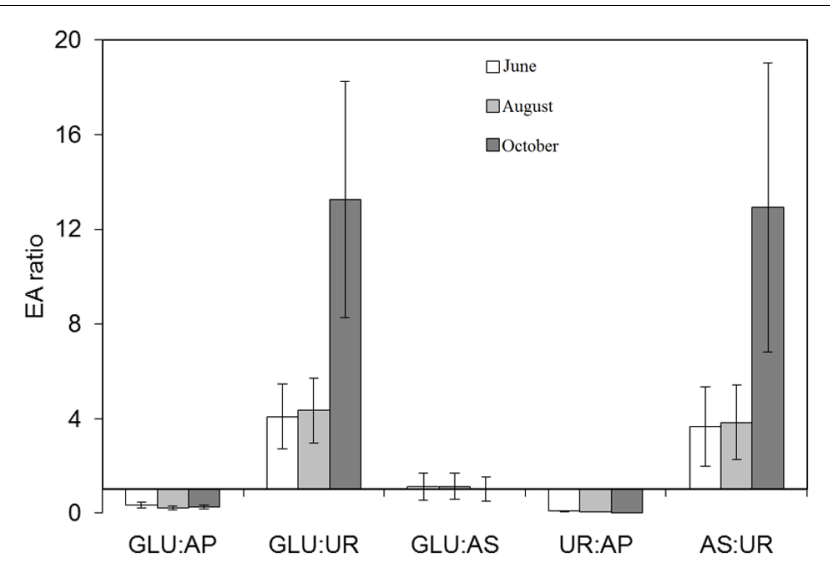

FIGURE 1 | Enzymatic activities (EA) ratios analyzed in sediment samples taken along the ice-free season on June 9, August 1, and October 13, 2015 in lake La Caldera (Sierra Nevada, Spain). GLU, $\beta$-glucosidase; UR, urease; AP, acid phosphatase, AS, arylsulphatase. $X$-axis is the threshold value $=1$. Error bars are calculated by propagation errors.

\section{$\mathrm{N}_{2} \mathrm{O}$ and $\mathrm{N}_{2}$ Emissions}

Production of $\mathrm{N}_{2} \mathrm{O}$ was detected in both sediment and water column samples of La Caldera lake (Table 2). Mean emissions of $\mathrm{N}_{2} \mathrm{O}$ diminished over the ice-free season. When acetylene was included to inhibit nitrous oxide reductase activity, production of $\mathrm{N}_{2} \mathrm{O}$ increased 5.2-, 4.7-, and 1.2-fold in sediments and 1.2-, 1.4-, and 1.4-fold in the water column from June to October. $\mathrm{N}_{2}$ emissions decreased following a similar pattern to that of $\mathrm{N}_{2} \mathrm{O}$ and values ranged from 538.9 to 7.4 ( $\mathrm{pmol} \mathrm{N}_{2} \mathrm{~g}^{-1}$ day $^{-1}$ ) in sediments between June and October and from 38.9 to 16.9 ( $\mathrm{pmol} \mathrm{N} \mathrm{g}^{-1}$ day $^{-1}$ ) in the water column.

\section{Abundance of 16S rRNA and nosZ Genes}

The average number of copies of the 16S rRNA and nos $Z$ clades I and II genes are shown in Table 3. The copy number of the $16 \mathrm{~S}$ rRNA gene per nanogram of DNA in June was significantly lower than those estimated in August and October Abundance of the nos $Z$ clade I gene was greater in August, followed by that found in October, and the lowest abundance in June. Differences in abundance of the nos $Z$ clade II gene were not detected in samples taken in June and October, which were lower than those estimated in August. This month showed the highest relative abundance of denitrifiers as revealed by the nos $Z$ (I + II)/16S
TABLE 3 | Relative abundance of $16 \mathrm{~S}$ rRNA and clade I and II nosZ genes in sediments from La Caldera lake (Sierra Nevada, Spain).

\begin{tabular}{lccc}
\hline & \multicolumn{3}{c}{ Sampling month } \\
\cline { 2 - 4 } & June & August & October \\
\hline 16S rRNA & $1.61 \times 10^{5} \mathrm{a}$ & $5.05 \times 10^{6} \mathrm{~b}$ & $2.90 \times 10^{6} \mathrm{~b}$ \\
nosZI & $2.91 \times 10^{2} \mathrm{a}$ & $5.68 \times 10^{4} \mathrm{c}$ & $1.79 \times 10^{3} \mathrm{~b}$ \\
nosZII & $2.31 \times 10^{2} \mathrm{a}$ & $5.57 \times 10^{3} \mathrm{~b}$ & $1.69 \times 10^{2} \mathrm{a}$ \\
nosZI/16S rRNA & $0.18 \mathrm{~b}$ & $1.12 \mathrm{c}$ & $0.06 \mathrm{a}$ \\
nosZII/16S rRNA & $0.14 \mathrm{~b}$ & $0.11 \mathrm{~b}$ & $0.01 \mathrm{a}$ \\
nosZI + nosZII/16S rRNA) & $0.32 \mathrm{~b}$ & $1.24 \mathrm{c}$ & $0.07 \mathrm{a}$ \\
\hline
\end{tabular}

Samples were taken on June 9, August 1, and October 13. Values are expressed as the number of copies of the gene per nanogram of DNA. For each row different letters indicate significant differences according to paired t-tests $(p \leq 0.05, n=4)$.

rRNA ratio in comparison with those estimated in June and October (Table 3). At all three sampling dates, percentage of denitrifiers containing the nosZI gene was higher than those with nosZII. In addition, clades I and II of nosZ genes had different seasonal pattern as members of clade II decreased over the ice-free period and those of clade I peaked at August.

\section{Analysis of Clone Libraries: Coverage and Diversity Indexes}

Three clone libraries containing each 40 nos $Z$ clade I genes were obtained corresponding to sediment samples taken in June, August, and October, respectively. Construction of a phylogenetic tree based on the 120 nos $Z$ sequences showed they distributed into eight clusters corresponding to uncultured bacteria and to genera Polymorphum, Paracoccus, Azospirillum, Pseudomonas, Hyphomicrobium, Thauera, and Methylophaga (Figure 2). Out of the 120 clones analyzed, members of the uncultured bacteria were the most abundant $(81.66 \%)$ followed by those of the classes Gammaproteobacteria (14.1\%), Alphaproteobacteria (3.3\%), and Betaproteobacteria (0.8\%). The Good's coverage index for each library was higher than $80 \%$, which indicates that the sampling effort was enough to permit extrapolations for analysis of total nos $Z$ gene biodiversity in the sediment samples. The diversity indices showed quite similar values between June and October genomic libraries (ShannonWiener index: 0.57-0.61, Simpson index: 0.27-0.27), and were higher for the August library (Shannon-Wiener index: 0.64, Simpson index: 0.39). Uncultured bacteria were the most

TABLE 2 | Production of nitrous oxide (pmol $\mathrm{N}_{2} \mathrm{O} \mathrm{g}^{-1}$ day $^{-1}$ ) in water column and sediments from La Caldera lake (Sierra Nevada, Spain).

\begin{tabular}{|c|c|c|c|c|c|c|}
\hline \multirow{3}{*}{ Treatment } & \multicolumn{6}{|c|}{ Sampling month } \\
\hline & \multicolumn{2}{|c|}{ June } & \multicolumn{2}{|c|}{ August } & \multicolumn{2}{|c|}{ October } \\
\hline & Sediment & Water & Sediment & Water & Sediment & Water \\
\hline Without acetylene & $128.3 \pm 32.2 \mathrm{c}$ & $198.4 \pm 39.3 c$ & $62.1 \pm 17.1 \mathrm{~b}$ & $71.4 \pm 19.5 b$ & $31.7 \pm 11.4 \mathrm{a}$ & $41.2 \pm 11.9 a$ \\
\hline With acetylene & $667.2 \pm 55.1 d$ & $237.3 \pm 39.7 c$ & $289.5 \pm 40.4 c$ & $96.4 \pm 22.1 b$ & $39.1 \pm 13.1 \mathrm{a}$ & $58.1 \pm 13.7 a$ \\
\hline
\end{tabular}

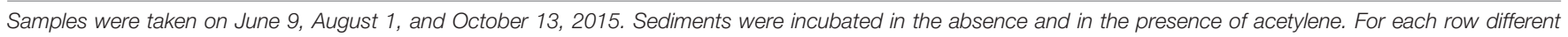
letters indicate significant differences according to paired t-tests ( $p \leq 0.05, n=5)$. 


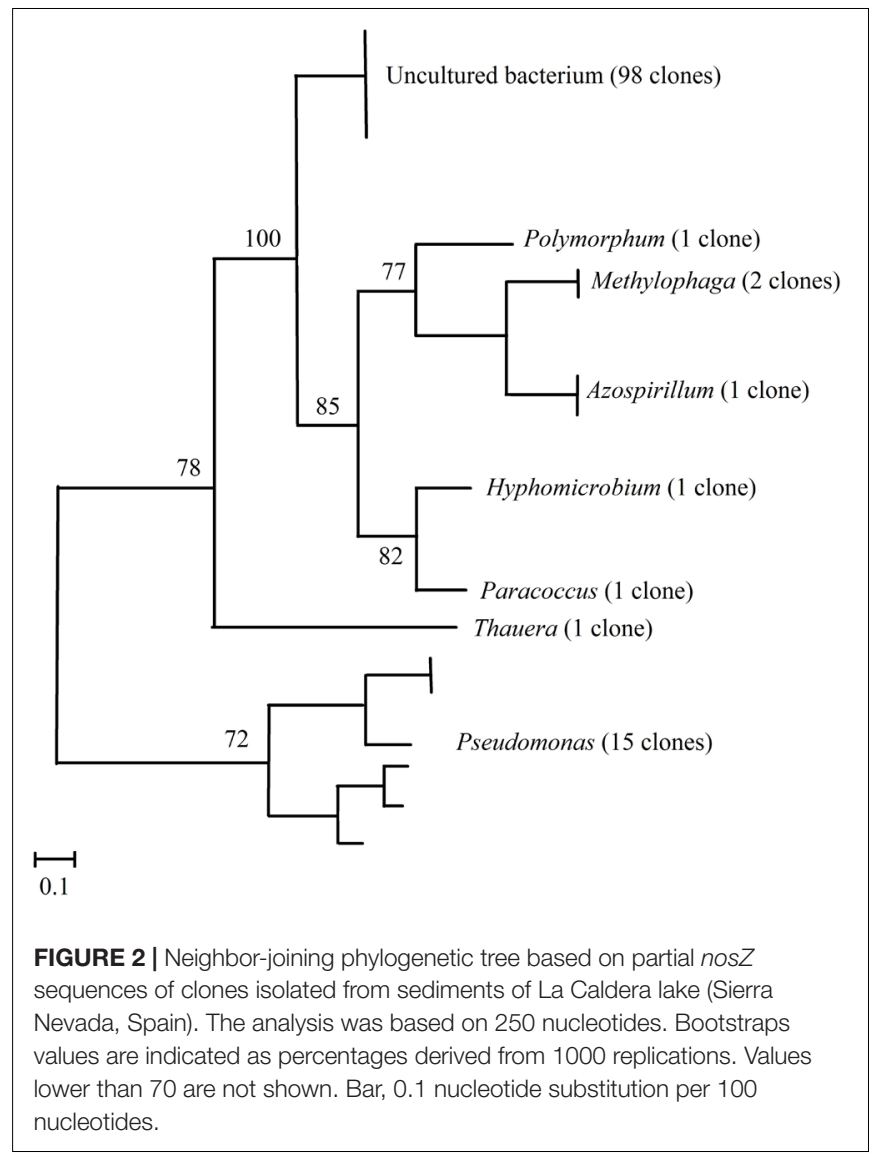

abundant in the three libraries $(34,30$, and 34 clones in June, August, and October, respectively). Pseudomonas was also present in the three libraries with three, nine, and three clones in June, August, and October, respectively. Genus Methylophaga was represented by two clones in the August library and the remaining genera were represented by one clone each.

\section{Linking Abundance of Targeted Genes with Environmental Variables in La Caldera Lake}

An NMDS plot showed that nosZI and nosZII genes grouped together and separated from the $16 \mathrm{~S}$ rRNA gene (Figure 3A). Relative abundance of the $16 \mathrm{~S}$ rRNA gene correlated $(r \geq 0.50)$ with the variables (in decreasing order of strength) TDP, DOC, TP, SRP, and $\mathrm{pH}$, whereas both the nos $\mathrm{Z}$ clades I and II genes correlated with the variables (in decreasing order of strength) temperature, $\mathrm{N}_{2} \mathrm{O}_{w}, \mathrm{~N}_{2} \mathrm{O}_{S}, \mathrm{NO}_{3}^{-}$, and $\mathrm{TN}(r \geq 0.50)$ (Figure 3B). According to the global permutation test, the significance of all vectors was $p<0.01$, which means that a sufficient number of data was used in the BIO-ENV analysis.

According to the BIO-ENV analysis, temperature, $\mathrm{NO}_{3}^{-}$, $\mathrm{N}_{2} \mathrm{O}_{s}$, and $\mathrm{N}_{2} \mathrm{O}_{w}$ were the best abiotic variables explaining (91.4\%) the ordination of the samples based on the changes of the biotic data (Figure 3B). An additional stepwise multiple regression analysis (Table 4) shows that variance of the $16 \mathrm{~S}$ rRNA gene abundance of La Caldera was explained mainly
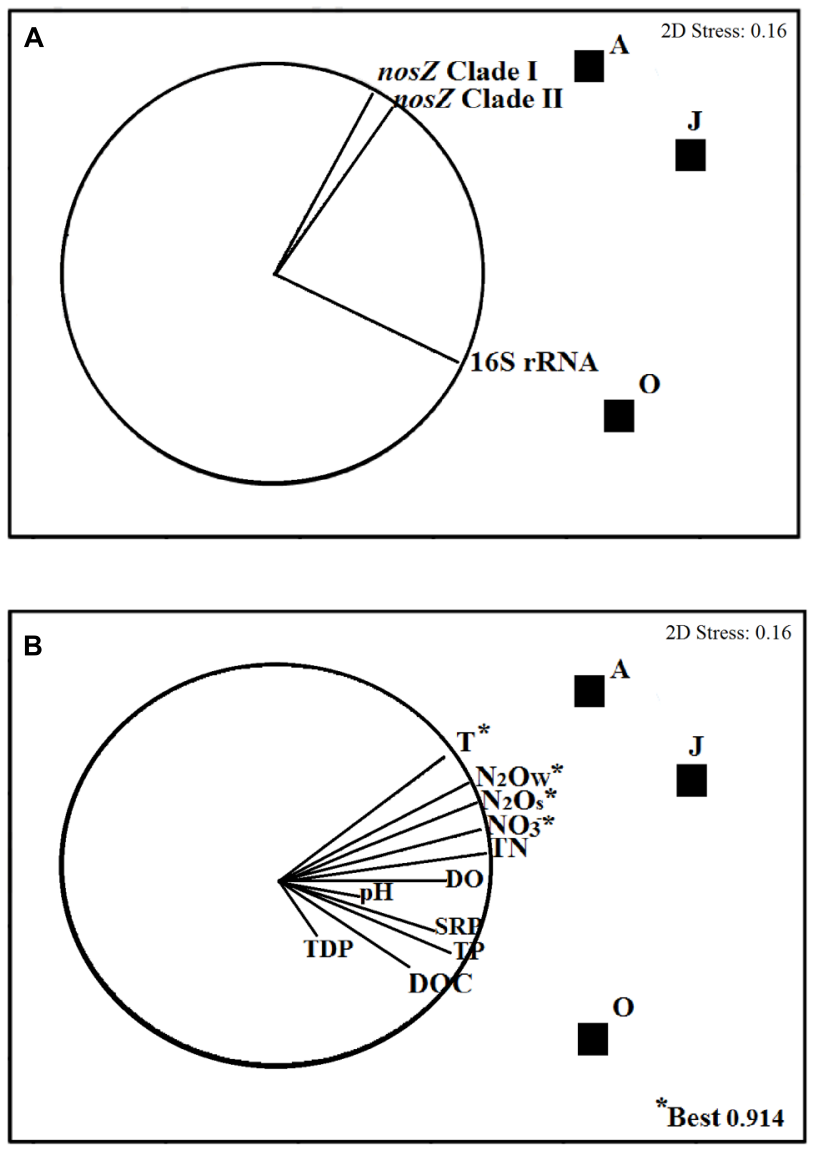

FIGURE 3 | Non-parametric multidimensional scaling (NMDS) plots illustrating ordinations of sediments samples from La Caldera lake (Sierra Nevada, Spain) over the ice-free season based on the abundance of copies of bacterial $16 S$ rRNA and nos $Z$ genes. Vectors in plots illustrate the direction and strength of the relationships between biotic (A) and abiotic variables (B). Sampling months are represented by squares (June; August; October). The variables which best explained the distributions of the biological data according to $\mathrm{BIO}-\mathrm{ENV}$ analysis are marked with an asterisk $\left({ }^{*}\right)$. T, temperature; $\mathrm{N}_{2} \mathrm{O}_{W}$, production of $\mathrm{N}_{2} \mathrm{O}$ by water columns; $\mathrm{N}_{2} \mathrm{O}_{S}$, production of $\mathrm{N}_{2} \mathrm{O}$ by sediments; $\mathrm{NO}_{3}^{-}$, nitrate content; TN, total nitrogen; DO, dissolved oxygen; SRP, reactive soluble phosphorus; TP, total phosphorus; DOC, dissolved organic carbon; TDP, total dissolve phosphorus. The $\mathrm{N}_{2} \mathrm{O}$ values used in plots are those obtained in samples that were incubated without acetylene.

by temperature $(31 \%)$ and $\mathrm{NO}_{3}^{-}(30 \%)$. However, the analysis also revealed that nos $Z$ clades I and II gene abundances were explained firstly by $\mathrm{NO}_{3}^{-}$(55 and $52 \%$, respectively), followed by $\mathrm{N}_{2} \mathrm{O}_{S}$ (21 and $20 \%$, respectively) and by $\mathrm{N}_{2} \mathrm{O}_{W}$ (15 and $17 \%$, respectively).

\section{Isolation of Denitrifying Bacteria from Sediments}

Preliminar experiments designed to know the best media, whether G2M11, G3M12, or G4M3 (Heylen et al., 2006), to be used for isolation of denitrifiers from the sediments showed that G3M12 allowed appearance of a greater number of CFUs and that those that appeared in the G2M11 and 
TABLE 4 | Multiple stepwise regression analysis among biotic-dependent variables (targeted genes abundance) and the independent variables that best explained NMDS ordination.

\begin{tabular}{|c|c|c|c|c|c|}
\hline Dependent variable & Independent variable & $\beta$ & Multiple $R^{2}$ & $R^{2}$ change & $p$ \\
\hline \multirow[t]{4}{*}{ 16S rRNA gene abundance } & $\mathrm{T}$ & 0.55 & 0.31 & 0.31 & 0.007 \\
\hline & $\mathrm{NO}_{3}^{-}$ & 0.51 & 0.61 & 0.30 & 0.008 \\
\hline & $\mathrm{N}_{2} \mathrm{O}_{W}$ & 0.23 & 0.72 & 0.11 & 0.018 \\
\hline & $\mathrm{N}_{2} \mathrm{O}_{S}$ & 0.21 & 0.82 & 0.10 & 0.035 \\
\hline \multirow[t]{4}{*}{ Clade I nos Z gene abundance } & $\mathrm{NO}_{3}^{-}$ & 0.80 & 0.55 & 0.55 & 0.001 \\
\hline & $\mathrm{N}_{2} \mathrm{O}_{S}$ & 0.33 & 0.76 & 0.21 & 0.011 \\
\hline & $\mathrm{N}_{2} \mathrm{O}_{W}$ & 0.26 & 0.91 & 0.15 & 0.022 \\
\hline & $\mathrm{T}$ & 0.11 & 0.97 & 0.06 & 0.035 \\
\hline \multirow[t]{4}{*}{ Clade II nosZ gene abundance } & $\mathrm{NO}_{3}^{-}$ & 0.76 & 0.52 & 0.52 & 0.001 \\
\hline & $\mathrm{N}_{2} \mathrm{O}_{S}$ & 0.29 & 0.72 & 0.20 & 0.012 \\
\hline & $\mathrm{N}_{2} \mathrm{O}_{W}$ & 0.27 & 0.89 & 0.17 & 0.016 \\
\hline & $\mathrm{T}$ & 0.18 & 0.97 & 0.08 & 0.037 \\
\hline
\end{tabular}

$\mathrm{NO}_{3}^{-}$, nitrate content; $\mathrm{N}_{2} \mathrm{O}$ w, production of $\mathrm{N}_{2} \mathrm{O}$ by water columns; $\mathrm{N}_{2} \mathrm{O}_{S}$, production of $\mathrm{N}_{2} \mathrm{O}$ by sediments; $T$, temperature; $\beta$, standardized regression coefficient;

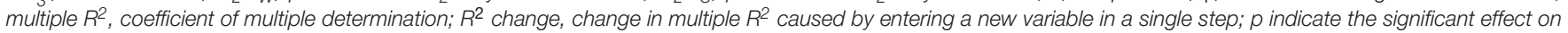
the considered variable.

G4M3 media were also present in G3M12 (data not shown). When that medium was used, 122 CFUs were obtained in June, a value that increased in the month of August to 209 and decreased to 52 in October. After morphological analysis, 31, 25, and 25 CFUs corresponding to June, August, and October, respectively, were selected which clustered in 29 different groups when subjected to REP-PCR (Table 5). Partial sequences of the $16 \mathrm{~S}$ rRNA gene from a representative strain of each REP group and pairwise alignments between globally aligned sequences showed they were closely related to members of genera Paracoccus, Polymorphum, Pseudomonas, Arthrobacter, Hyphomicrobium, Azospirillum, Methylophaga, Thauera, Burkholderia, and Rhizobium (Table 5), of which Arthrobacter, Burkholderia, and Rhizobium had not been detected in the clone libraries. The representative strains used in this study can be considered as true denitrifiers as, after identification, they all were capable of growing again in G3M12 medium.

\section{DISCUSSION}

Despite increases in global $\mathrm{Nr}$ deposition, previous studies have consistently observed a regional pattern of decreasing DIN in recent decades in the Pyrenean lakes (Camarero and Catalán, 2012) as well as an inter-annually seasonal trend of decreasing DIN in the Sierra Nevada lakes, as La Caldera (Carrillo et al., 1996; Medina-Sánchez et al., 1999; Delgado-Molina et al., 2009). The latter trend can be also elicited from data reported in other studies on high altitude mountain lakes (Tiberti et al., 2013; Porcal et al., 2014; Santolaria et al., 2015). While P deposition can play a role in these trends (Camarero and Catalán, 2012), the present study extends those findings by showing it is likely the loss of $\mathrm{N}$ could be due to denitrification activity. As expected, $\mathrm{NO}_{3}^{-}$concentration decreased over the sampling dates and this was the predominant $\mathrm{N}$ form found in the lake (Table 1).
Although UVR radiation has been involved in nitrate removal by photoreduction or photolysis (Brezonik and FulkersonBrekken, 1998; Porcal et al., 2014), $K_{d}$ and DOC variations over the ice-free period did not match those of $\mathrm{NO}_{3}^{-}$(Table 1 and Supplementary Figure S2). Thus, it is unlikely that UV radiation is a main factor involved in nitrate removal in this ecosystem. On the other hand, our results indicate that decreases in $\mathrm{NO}_{3}^{-}$content were not associated with $\mathrm{N}$-uptake due to the growth of the microbial plankton. This is in agreement with previous results which show that DIN in La Caldera lake did not relate to MPB or growth during the ice-free season (Villar-Argaiz et al., 2001; Carrillo et al., 2002; MedinaSánchez et al., 2004; Dorado-García et al., 2014; Durán et al., 2016). In fact, $N$ was not the main limiting nutrient for microbial plankton growth in the lake as indicated by the EA related to $\mathrm{C}, \mathrm{N}, \mathrm{P}$, and $\mathrm{S}$ cycles. Given the link between the microbial metabolism and environmental energy/resource availability provided by the ratios between EA (Sinsabaugh et al., 2009; Sinsabaugh and Follstad-Shah, 2012), the calculated ratios in our study (GLU:AP < 1; GLU:UR > 1; GLU:AS 1, $\mathrm{UR}: \mathrm{AP}<1$; AS:UR $>1$ ) indicate a resource limitation ordered as $\mathrm{P}>\mathrm{C}=\mathrm{S}>\mathrm{N}$, an order which was even intensified over the ice-free period (Figure 1). This is consistent with the patterns of resource limitation found in La Caldera under events of Saharan dust-aerosol deposition (Velasco-Ayuso et al., 2017).

Despite the relatively low nitrate concentration, denitrification activity, measured as $\mathrm{N}_{2} \mathrm{O}$ production, was detected both in the water column and in the sediments (Table 2). On average, the presence of acetylene during assays for denitrification increased $\mathrm{N}_{2} \mathrm{O}$ production by 61 and $38 \%$ in the sediments and in the water column, respectively (Table 2), which points to the presence of a bacterial community with the capacity to carry out the complete denitrification process and, therefore, the ability to produce $\mathrm{N}_{2}$ as a final denitrification product. It is unlikely that nitrifiers substantially contributed to $\mathrm{N}_{2} \mathrm{O}$ production in La Caldera as the content of ammonium in 
TABLE 5 | REP-PCR groups and taxonomic identification of representative strains isolated from sediments of La Caldera lake (Sierra Nevada, Spain) taken on June 9, August 1, and October 13, 2015.

\begin{tabular}{|c|c|c|c|}
\hline $\begin{array}{l}\text { REP-PCR } \\
\text { group }\end{array}$ & Strains & $\begin{array}{l}\text { Closest relative } \\
\text { genus on basis of } \\
\text { 16S rRNA gene }\end{array}$ & $\begin{array}{c}\text { Similarity } \\
\text { according to } \\
\text { EzTaxon-e (\%) }\end{array}$ \\
\hline I & J14 & Paracoccus & 97 \\
\hline$\|$ & A25 & Polymorphum & 96 \\
\hline III & JX3 & Paracoccus & 97 \\
\hline IV & A7, J3 & Pseudomonas & 98 \\
\hline V & 013 & Pseudomonas & 99 \\
\hline VI & $\mathbf{J} 7$ & Arthrobacter & 99 \\
\hline VII & $\begin{array}{c}\text { 012, } 011,08, \\
\text { 010, 09, O3, } \\
\text { 05, O2, O4 }\end{array}$ & Pseudomonas & 99 \\
\hline VIII & A14 & Hyphomicrobium & 97 \\
\hline IX & A18, 01 & Pseudomonas & 98 \\
\hline$x$ & 07, 06, J6 & Pseudomonas & 99 \\
\hline$X I$ & J1, J4 & Azospirillum & 97 \\
\hline XII & 015 & Pseudomonas & 97 \\
\hline XIII & A3, A4, J23 & Pseudomonas & 88 \\
\hline XIV & JX4, О20 & Pseudomonas & 97 \\
\hline$X V$ & A19, A16 & Methylophaga & 97 \\
\hline $\mathrm{XVI}$ & JX6, O17 & Pseudomonas & 97 \\
\hline$X V I I$ & 019 & Pseudomonas & 96 \\
\hline XVIII & 014, O16 & Thauera & 97 \\
\hline$I X X$ & $\begin{array}{l}\text { J21, A1, A10, } \\
\text { A11, A12, A17 }\end{array}$ & Pseudomonas & 99 \\
\hline$X X$ & J19, J22, J25 & Paracoccus & 97 \\
\hline$X X I$ & J18, JX1 & Paracoccus & 96 \\
\hline$X X \|$ & J12 & Burkholderia & 92 \\
\hline$X X I I I$ & A2 & Rhizobium & 100 \\
\hline XIV & A20, A21, A23 & Methylophaga & 99 \\
\hline$X X V$ & 022, J8, O23 & Pseudomonas & 97 \\
\hline XXVI & 025, O24, О21 & Methylophaga & 100 \\
\hline
\end{tabular}

Strains in bold were chosen as the representative of each REP-PCR group.

the water column and sediments was negligible (data not shown). Relative contribution of sediment vs. water column to denitrification is difficult to estimate due to the inherent strong variations of size of both compartments intra- and interannually.

Assays based on the presence of the nos $Z$ genes (clades I and II), or gene products, which catalyzes the reduction of $\mathrm{N}_{2} \mathrm{O}$ to $\mathrm{N}_{2}$, have successfully been used to relate community structure to denitrification (Throbäck et al., 2004; Peralta et al., 2010; Deslippe et al., 2014; Tatti et al., 2015; Barrett et al., 2016). Denitrifiers of both nosZI and nosZII clades were present in the sediments, and variations in their dynamics paralleled those of the total number of bacteria after determination by quantification of the 16S rRNA gene (Table 3). Because denitrifiers of clades I and II nos $Z$ genes has also been shown in sediments of boreal lakes (Saarenheimo et al., 2015a), our study reinforces the relevance of studying nosZI and nosZII genes in aquatic ecosystems.

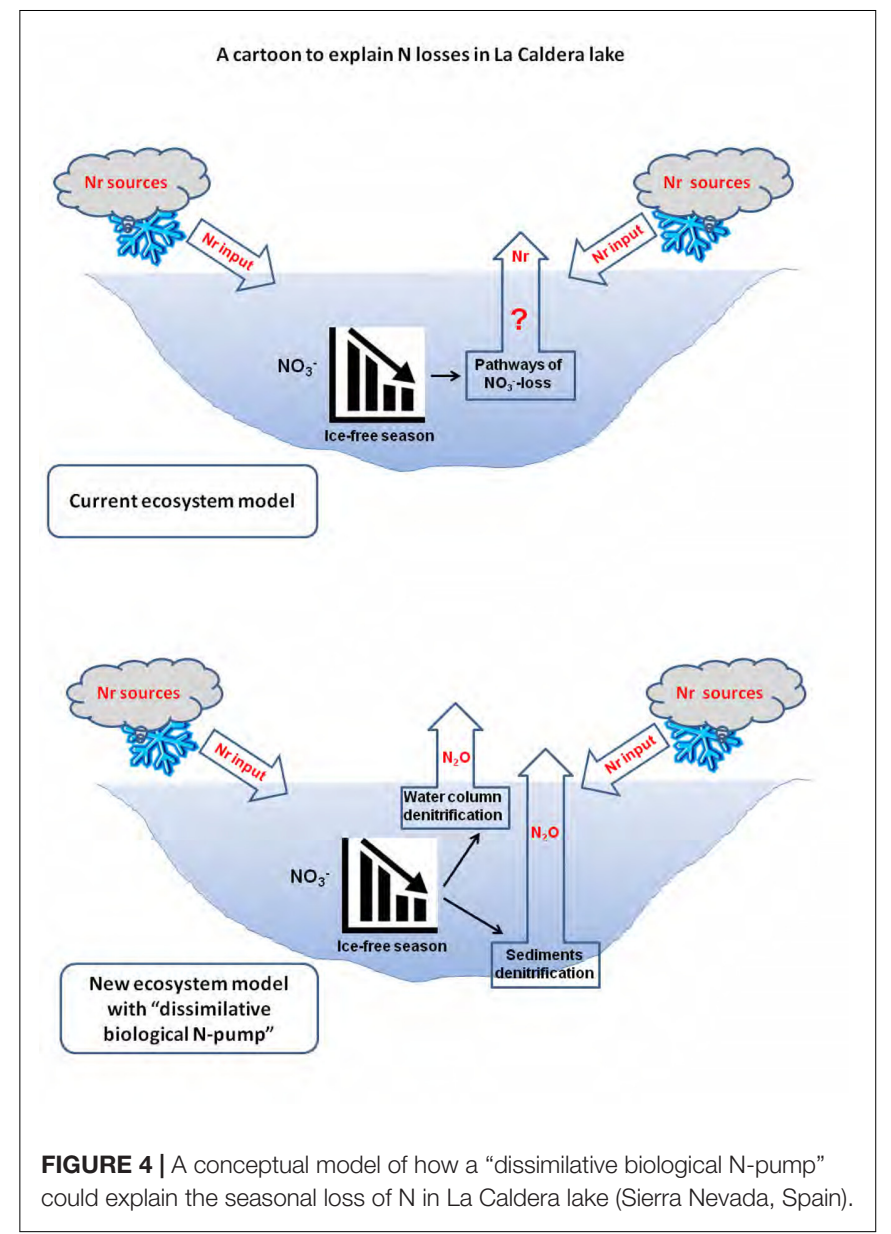

Diversity of bacterial denitrifiers in the lake was estimated by construction of clone libraries using the nos $Z$ clades I and II genes as molecular markers. Altogether, genera found in the three clone libraries were Polymorphum, Paracoccus, Azospirillum, and Hyphomicrobium of the phylum Alphaproteobacteria, Thauera of the phylum Betaproteobacteria, Pseudomonas of the phylum Gammaproteobacteria, and Methylophaga of the Gammaproteobacteria, though $81.67 \%$ of the 120 sequences in the libraries corresponded to unclassified bacteria (Figure 2), which indicates the presence of hitherto uncultured bacterial groups in high-mountain lakes. Scala and Kerkhoff (2000) also found that uncultured bacteria were predominant when analyzing denitrifying communities in marine sediments. Among the identified genera, Pseudomonas was the most abundant and was found in samples from the three sampling dates (Figure 2 and Supplementary Table S2). Our data, however, contrast with those obtained by pyrosequencing which indicate that genera Burkholderia, Azospirillum, and Ochrobactrum were the core nosZ-OTUs found in boreal lakes (Saarenheimo et al., 2015b). Values of the Shannon-Wiener and Simpson indexes for the JCL and OCL clone libraries were similar, and lower than those for the ACL library, which indicates that biodiversity of denitrifying bacteria was higher in August, coinciding with the highest water temperature (Table 1). Thus, NMDS ordinations (Figure 3) 
revealed that temperature, $\mathrm{NO}_{3}^{-}$, and $\mathrm{N}_{2} \mathrm{O}$ emissions showed strong positive correlation with the abundance of denitrifiers. Positive correlations between $\mathrm{N}$ availability and denitrification capability have also been shown in boreal lakes (Kortelainen et al., 2000; Rissanen et al., 2011, 2013; Saarenheimo et al., 2015a).

The culture-dependent approach used in this study to isolate denitrifying bacteria from the lake La Caldera resulted in obtaining a total of 383 CFUs that grouped in 26 REP clusters. REP-PCR fingerprinting has been extensively used to cluster bacteria at the subspecies of strain level (de Bruijn, 1992) and is known to be a powerful tool for studies on microbial ecology and evolution (Ishii and Sadowsky, 2009). Interestingly, genera Arthrobacter, Burkholderia, and Rhizobium were identified that had not been detected in the clone libraries. This suggests that both culture-dependent and -independent methods are complementary to study bacterial biodiversity.

\section{CONCLUSION}

Taken together, our results provide evidence for a noteworthy role of bacterial denitrification as a "dissimilative biological $\mathrm{N}$-pump" in the water column and sediments that shapes the $\mathrm{N}$ cycle and explain the decreasing $\mathrm{NO}_{3}^{-}$content over the ice-free period in oligotrophic high-mountain lakes as $\mathrm{La}$ Caldera (Figure 4). In this study, environmental conditions, particularly the non-limiting $\mathrm{N}$ content, allowed $\mathrm{N}_{2} \mathrm{O}$ production and determined denitrifiers' community structure. Therefore, this study provides evidence that denitrification can act as an auto-depurative mechanism for removal of contaminant nitrates in high-mountains lakes. Moreover, in other types of lakes where nitrate loads are higher, and non-limiting for plankton growth, denitrification is expected to be enhanced, which requires further research.

\section{REFERENCES}

APHA (2005). Standard Methods for the Examination of Water and Wastewater. Washington, DC: American Public Health Association.

Barrett, M., Khalil, M. I., Jahangir, M. M., Lee, C., Cardenas, L. M., Collins, G., et al. (2016). Carbon amendment and soil depth affect the distribution and abundance of denitrifiers in agricultural soils. Environ. Sci. Pollut. Res. 23, 7899-7910. doi: 10.1007/s11356-015-6030-1

Bartrons, M., Catalan, J., and Casamayor, E. O. (2012). High bacterial diversity in epilithic biofilms of oligotrophic mountain lakes. Microb. Ecol. 64, 860-869. doi: 10.1007/s00248-012-0072-4

Bedmar, E. J., Bueno, E., Correa-Galeote, D., Torres, M. J., Delgado, M. J., and Mesa, S. (2013). "Ecology of denitrification in soils and plant-associated bacteria," in Beneficial Plant-Microbial Interactions: Ecology and Applications, eds M. B. Rodelas and J. González-López (Boca Ratón, FL: CRC Press), 164-182.

Brahney, J., Mahowald, N., Ward, D. S., Ballantyne, A. P., and Neff, J. C. (2015). Is atmospheric phosphorus pollution altering global alpine Lake stoichiometry? Global Biogeochem. Cycles 29, 1369-1383. doi: 10.1002/2015GB005137

Brezonik, P., and Fulkerson-Brekken, J. (1998). Nitrate-induced photolysis in natural waters: controls on concentrations of hydroxyl radical photointermediates by natural scavenging agents. Environ. Sci. Technol. 32, 3004-3010. doi: 10.1021/es 9802908

Burgin, A. J., and Hamilton, S. K. (2007). Have we overemphasized the role of dentirification in aquatic ecosystems? A review of nitrate removal pathways.

\section{AUTHOR CONTRIBUTIONS}

EB and JM-S conceived and designed the experiments. AC-H, DC-G, and JM-S performed the experiments. EB, PC, JM-S, and AC-H analyzed the data. EB, PC, and JM-S contributed reagents/materials/analysis tools. $\mathrm{EB}, \mathrm{JM}-\mathrm{S}, \mathrm{PC}$, and $\mathrm{AC}-\mathrm{H}$ wrote the paper.

\section{FUNDING}

This study was supported by the University of Granada (UGR)-CEI-Biotic-sponsored project ST2-2015, the ERDFcofinanced grants PE2012-AGR1968 and P12-RNM-327 from Consejería de Empleo, Empresa y Comercio (Junta de Andalucía, Spain), and CGL2015-67682-R from Ministerio de Economía y Competitividad (Spain). AC-H is a recipient of grant FPU14/01633 awarded by MECD.

\section{ACKNOWLEDGMENTS}

We are also grateful to Manuel J. López-Rodríguez and M. VillarArgaiz for support and critical reading of the manuscript, and to Ismael L. Lozano and J. M. González-Olalla for field and laboratory assistance. We are indebted to the staff of Sierra Nevada National Park for working permits.

\section{SUPPLEMENTARY MATERIAL}

The Supplementary Material for this article can be found online at: https://www.frontiersin.org/articles/10.3389/fmicb. 2017.01911/full\#supplementary-material

Front. Ecol. Environ. 5, 89-96. doi: 10.1890/1540-9295(2007)5[89:HWOTRO] 2.0.CO;2

Cabrerizo, M. J., Medina-Sánchez, J. M., Dorado-García, I., Villar-Argaiz, M., and Carillo, P. (2017). Rising nutrient-pulse frequency and high UVR strenthen microbial interactions. Sci. Rep. 7:43615. doi: 10.1038/ srep43615

Camarero, L., and Catalán, J. (2012). Atmospheric phosphorus deposition may cause lakes to revert from phosphorus limitation back to nitrogen limitation. Nat. Commun. 3:1118. doi: 10.1038/ncomms 2125

Carrillo, P. I, Reche, I., and Cruz-Pizarro, L. (1996). Intraspecific stoichiometric variability and the ratio of nitrogen to phosphorus resupplied by zooplankton. Freshw. Biol. 36, 363-374. doi: 10.1046/j.1365-2427.1996.00091.x

Carrillo, P., Medina-Sánchez, J. M., Durán, C., Herrera, G., Villafañe, V. E., and Helbling, E. W. (2015). Synergistic effects of UVR and simulated stratification on commensalistic phytoplankton-bacteria relationship in two optically contrasting oligotrophic Mediterranean lakes. Biogeosciences 12, 697-712. doi: 10.5194/bg-12-697-2015

Carrillo, P., Medina-Sánchez, J. M., and Villar-Argaiz, M. (2002). The interaction of phytoplankton and bacteria in a high mountain lake: importance of the spectral composition of solar radiation. Limnol. Oceanogr. 47, 1294-1306. doi: 10.4319/lo.2002.47.5.1294

Carrillo, P., Medina-Sánchez, J. M., and Villar-Argaiz, M. (2008). Does microorganism stoichiometry predict microbial food web interactions after a phosphorus pulse? Microb. Ecol. 56, 350-363. doi: 10.1007/s00248-007-9353-8 
Carrillo, P., Medina-Sánchez, J. M., Villar-Argaiz, M., Delgado-Molina, J. A., and Bullejos, F. J. (2006). Complex interactions in microbial food webs: stoichiometric and functional approaches. Limnetica 25, 189-204.

Catalán, J. (1992). Evolution of dissolved and particulate matter during the icecovered period in a deep, high mountain lake. Can. J. Fish. Aquat. Sci. 49, 945-955. doi: 10.1139/f92-105

Catalán, J., Ballesteros, E., Gacia, E., Palau, A., and Camarero, L. (1993). Chemical composition of disturbed and undisturbed high mountain lakes in the Pyrenees: a reference for acidified sites. Water Res. 27, 133-141. doi: 10.1016/00431354(93)90203- T

Catalán, J., Camarero, L., Felip, M., Pla, S., Ventura, M., Buchaca, T., et al. (2006). High mountain lakes: extreme habitats and witnesses of environmental changes. Limnetica 25, 551-584.

Clarke, K. R., Somerfield, P. J., and Gorley, R. N. (2008). Testing of null hypotheses in exploratory community analyses: similarity profiles and biota-environment linkage. J. Exp. Mar. Biol. Ecol. 366, 56-69. doi: 10.1016/j.jembe.2008.07.009

Clarke, K. R., and Warwick, R. (2001). Change in Marine Communities: An Approach to Statistical Analysis and Interpretation. Plymouth: Plymouth Marine Laboratory.

Correa-Galeote, D., Marco, D. E., Tortosa, G., Bru, D., Philippot, L., and Bedmar, E. J. (2013). Spatial distribution of N-cycling microbial communities showed complex patterns in constructed wetland sediments. FEMS. Microbiol. Ecol. 83, 340-351. doi: 10.1111/j.1574-6941.2012.01479.x

de Bruijn, F. J. (1992). Use of repetitive sequences and the polymerase chain reaction to fingerprint the genomes of Rhizobium meliloti isolates and other soil bacteria. Appl. Environ. Microbiol. 58, 2180-2187.

Delgado-Molina, J. A., Carrillo, P., Medina-Sánchez, J. M., Villar-Argaiz, V., and Bullejos, F. J. (2009). Interactive effects of phosphorus loads and ambient ultraviolet radiation on the algal community in a high-mountain lake. J. Plankton Res. 31, 619-634. doi: 10.1093/plankt/fbp018

Deslippe, J. R., Jamali, H., Jha, N., and Saggar, S. (2014). Denitrifier community size, structure and activity along a gradient of pasture to riparian soils. Soil Biol. Biochem. 71, 48-60. doi: 10.1016/j.soilbio.2014.01.007

Dorado-García, I., Medina-Sánchez, J. M., Herrera, G., Cabrerizo, M. J., and Carrillo, P. (2014). Quantification of carbon and phosphorus co-limitation in bacterioplankton: new insights on an old topic. PLOS ONE 9:e99288. doi: 10.1371/journal.pone.0099288

Durán, C., Medina-Sánchez, J. M., Herrera, G., and Carrillo, P. (2016). Changes in the phytoplankton-bacteria coupling triggered by joint action of UVR, nutrients, and warming in Mediterranean high-mountain lakes. Limnol. Oceanogr. 61, 413-429. doi: 10.1002/lno.10204

El Batanony, N. H., Castellano-Hinojosa, A., Correa-Galeote, D., and Bedmar, E. J. (2015). The diversity of rhizobia nodulating the Medicago, Melilotus and Trigonella inoculation group in Egypt is marked by the dominance of two genetic types. Symbiosis 67, 3-10. doi: 10.1007/s13199-015-0365-8

Elser, J. J., Andersen, T., Baron, J. S., Bergström, A. K., Jansson, M., Kyle, M., et al. (2009a). Shifts in lake N:P stoichiometry and nutrient limitation driven by atmospheric nitrogen deposition. Science 326, 835-837. doi: 10.1126/science. 1176199

Elser, J. J., Kyle, M., Steuer, L., Nydick, K. R., and Baron, J. S. (2009b). Nutrient availability and phytoplankton nutrient limitation across a gradient of atmospheric nitrogen deposition. Ecology 90, 3062-3073. doi: 10.1890/08-1742

Erisman, B. E., Allen, L. G., Pondella, D. J., Claisse, J., Miller, E., and Murray, J. (2011). Illusions of plenty: hyperstability masks collapses in two recreational fisheries that target fish spawning aggregations. Can. J. Fish. Aquat. Sci. 68, 1705-1716. doi: 10.1139/f2011-09

Erisman, J. W., Galloway, J. N., Dice, N. B., Sutton, M. A., Bleeker, A., Grizzetii, B., et al. (2015). Nitrogen: Too Much of a Vital Resource. Science Brief. Zeist: WWF Netherlands.

Erisman, J. W., Galloway, J. N., Seitzinger, S., Bleeker, A., Dise, N. B., Petrescu, R., et al. (2013). Consequences of human modification of the global nitrogen cycle. Philos. Trans. R. Soc. B 368, 20130116. doi: 10.1098/rstb.2013.0116

Fowler, D., Coyle, M., Skiba, U., Sutton, M. A., Cape, J. N., Reis, S., et al. (2013). The global nitrogen cycle in the twenty-first century. Philos. Trans. R. Soc. B 368, 20130164. doi: 10.1098/rstb.2013.0164

Galloway, J. N., Leach, A. M., Bleeker, A., and Erisman, J. W. (2013). A chronology of human understanding of the nitrogen cycle. Philos. Trans. R. Soc. B 368, 20130120. doi: 10.1098/rstb.2013.0120
Galloway, J. N., Townsend, A. R., Erisman, J. W., Bekunda, M., Cai, Z., Freney, J. R., et al. (2008). Transformation of the nitrogen cycle: recent trends, questions, and potential solutions. Science 320, 889-892. doi: 10.1126/science.1136674

García, C., Hernández, T., and Costa, F. (1997). Potential use of dehydrogenase activity as an index of microbial activity in degraded soils. Commun. Soil Sci. Plant Anal. 28, 123-134. doi: 10.1080/00103629709369777

García-Gómez, H., Garrido, J. L., Vivanco, M. G., Lassaletta, L., Rábago, I., Àvila, A., et al. (2014). Nitrogen deposition in Spain: modeled patterns and threatened habitats within the Natura 2000 network. Sci. Total. Environ. 48, 450-460. doi: 10.1016/j.scitotenv.2014.03.112

Gąsiorowski, M., and Sienkiewicz, E. (2013). The sources of carbon and nitrogen in mountain lakes and the role of human activity in their modification determined by tracking stable isotope composition. Water Air Soil Pollut. 224:1498. doi: 10.1007/s11270-013-1498-0

Halm, H., Musat, N., Lam, P., Langlois, R., Musat, F., Peduzzi, S., et al. (2009). Cooccurrence of denitrification and nitrogen fixation in a meromictic lake, Lake Cadagno (Switzerland). Environ. Microbiol. 11, 1945-1958. doi: 10.1111/j.14622920.2009.01917.x

Henry, S., Bru, D., Stres, B., Hallet, S., and Philippot, L. (2006). Quantitative detection of the nos $Z$ gene, encoding nitrous oxide reductase, and comparison of the abundances of $16 \mathrm{~S}$ rRNA, narG, nirK, and nosZ genes in soils. Appl. Environ. Microbiol. 72, 5181-5189. doi: 10.1128/AEM.00231-06

Herrera-Cervera, J. A., Cabello-Mellado, J., Laguerre, G., Tichy, H. V., Requena, N., Amarger, N., et al. (1999). At least five rhizobial species nodulate Phaseolus vulgaris in a Spanish soils. FEMS Microbiol. Ecol. 30, 87-97. doi: 10.1111/j.15746941.1999.tb00638.x

Hertel, T. W., Ramankutty, N., and Baldos, U. L. C. (2014). Global market integration increases likelihood that a future African Green Revolution could increase crop land use and CO2 emissions. Proc. Natl. Acad. Sci. U.S.A. 111, 13799-13804. doi: 10.1073/pnas.1403543111

Heylen, K., Vanparys, B., Wittebolle, L., Verstraete, W., Boon, N., and De Vos, P. (2006). Cultivation of denitrifying bacteria: optimisation of isolation conditions and diversity study. Appl. Environ. Microbiol. 72, 2637-2643. doi: 10.1128/ AEM.72.4.2637-2643.2006

IPCC (2013). "Summary for policymakers," in Climate Change 2013: The Physical Science Basis, eds T. F. Stocker, D. Qin, G. K. Plattner, M. Tignor, S. K. Allen, J. Boschung, et al. (Cambridge: Cambridge University Press).

Ishii, S., and Sadowsky, M. J. (2009). Applications of the rep-PCR DNA fingerprinting technique to study microbial diversity, ecology and evolution. Environ. Microbiol. 11, 733-740. doi: 10.1111/j.1462-2920.2008.01856.x

Jones, C. M., Graf, D. R., Bru, D., Philippot, L., and Hallin, S. (2012). The unaccounted yet abundant nitrous oxide-reducing microbial community: a potential nitrous oxide sink. ISME J. 7, 417-426. doi: 10.1038/ismej. 2012.125

Kandeler, E., and Gerber, H. (1988). Short-term assay of soil urease activity using colorimetric determination of ammonium. Biol. Fertil. Soils 6, 68-72. doi: 10. 1007/BF00257924

Kim, O. S., Cho, Y. J., Lee, K., Yoon, S. H., Kim, M., Na, H., et al. (2012). Introducing EzTaxon-e: a prokaryotic 16S rRNA gene sequence database with phylotypes that represent uncultured species. Int. J. Syst. Evol. Microbiol. 62, 716-721. doi: 10.1099/ijs.0.038075-0

Kortelainen, P., Huttunen, J. T., Väisänen, T., Mattsson, T., Karjalainen, P., and Martikainen, P. J. (2000). CH4, CO2 and N2O supersaturation in 12 Finnish lakes before and after ice-melt. Verh. Internat. Verein. Limnol. 27, 1410-1414.

Kumar, S., Stecher, G., and Tamura, K. (2015). MEGA7: Molecular Evolutionary Genetics Analysis version 7.0 for bigger datasets. Mol. Biol. Evol. 3, 1870-1874. doi: 10.1093/molbev/msw054

López-Gutiérrez, J. C., Henry, S., Hallet, S., Martin-Laurent, F., Catroux, G., and Philippot, L. (2004). Quantification of a novel group of nitrate-reducing bacteria in the environment by real-time PCR. J. Microbiol. Methods 57, 399-407. doi: 10.1016/j.mimet.2004.02.009

Medina-Sánchez, J. M., Delgado-Molina, J. A., Bratbak, G., Bullejos, F. J., VillarArgaiz, M., and Carrillo, P. (2013). Maximum in the middle: nonlinear response of microbial plankton to ultraviolet radiation and phosphorus. PLOS ONE 8:e60223. doi: 10.1371/journal.pone.0060223

Medina-Sánchez, J. M., Villar-Argaiz, M., and Carrillo, P. (2004). Neither with nor without you: a complex algal control on bacterioplankton in a high mountain lake. Limnol. Oceanogr. 49, 1722-1733. doi: 10.4319/lo.2004.49.5.1722 
Medina-Sánchez, J. M., Villar-Argaiz, M., Sánchez-Castillo, P., Cruz-Pizarro, L., and Carrillo, P. (1999). Structure changes in a planktonic food web: biotic and abiotic controls. J. Limnol. 58, 213-222. doi: 10.4081/jlimnol.1999.213

Miller, J. (1972). Experiments in Molecular Genetics. Cold Spring Harbor, NY: Cold Spring Harbor Laboratory.

Morales-Baquero, R., and Pérez-Martínez, C. (2016). Saharan versus local influence on atmospheric aerosol deposition in the southern Iberian Peninsula: significance for $\mathrm{N}$ and $\mathrm{P}$ inputs. Glob. Biogeochem. Cycle 30, 501-513. doi: 10.1002/2015GB005254

Morales-Baquero, R., Pulido-Villena, E., and Reche, I. (2006). Atmospheric inputs of phosphorus and nitrogen to the southwest Mediterranean region: biogeochemical response of high mountain lakes. Limnol. Oceanogr. 51, 830-837. doi: 10.4319/lo.2006.51.2.0830

Peralta, A. L., Matthews, J. W., and Kent, J. W. (2010). Microbial community structure and denitrification in a wetland mitigation bank. Appl. Environ. Microbiol. 76, 4207-4215. doi: 10.1128/AEM.02977-09

Porcal, P., Kopáček, J., and Tomková, I. (2014). Seasonal photochemical transformations of nitrogen species in a forest stream and lake. PLOS ONE 9:e116364. doi: 10.1371/journal.pone.0116364

Ravishankara, A. R., Daniel, J. S., and Portmann, R. W. (2009). Nitrous Oxide (N2O): the dominant ozone-depleting substance emitted in the 21st century. Science 326, 123-125. doi: 10.1126/science.117698

Reboleiro-Rivas, P., Juárez-Jiménez, B., Martínez-Toledo, M. V., Rodelas, B., Andrade, L., Gonzalez-Lopez, J., et al. (2013). Bacterial communities' structure in a high mountain lake during the ice-free season: cultural and PCR-TGGE investigations. Int. J. Environ. Res. 7, 685-696.

Richardson, D. J. (2011). "Redox complexes of the nitrogen cycle," in Nitrogen Cycling in Bacteria: Molecular Analysis, ed. J. W. B. Moir (Poole: Caister Academic Press), 23-37.

Rissanen, A. J., Tiirola, M., Hietanen, S., and Ojala, A. (2013). Interlake variation and environmental controls of denitrification across different geographical scales. Aquat. Microb. Ecol. 69, 1-16. doi: 10.3354/ame0161

Rissanen, A. J., Tiirola, M., and Ojala, A. (2011). Spatial and temporal variation in denitrification and in the denitrifier community in a boreal lake. Aquat. Microb. Ecol. 64, 27-40. doi: 10.3354/ame01506

Rockström, J., Steffen, W., Noone, K., Persson, A., Stuart, F., Lambin, E. F., et al. (2009). A safe operating space for humanity. Nature 461, 472-475. doi: 10.1038/ $461472 \mathrm{a}$

Saarenheimo, J., Rissanen, A. J., Arvola, L., Nykänen, H., Lehmann, M. F., and Tiirola, M. (2015a). Genetic and environmental controls on nitrous oxide accumulation in lakes. PLOS ONE 10:e0121201. doi: 10.1371/journal.pone. 0121201

Saarenheimo, J., Tiirola, M. A., and Rissanen, A. J. (2015b). Functional gene pyrosequencing reveals core proteobacterial denitrifiers in boreal lakes. Front. Microbiol. 6:674. doi: 10.3389/fmicb.2015.00674

Santolaria, Z., Arruebo, T., Urieta, J. S., Lanaja, F. J., Pardo, A., Matesanz, J., et al. (2015). Hydrochemistry dynamics in remote mountain lakes and its relation to catchment and atmospheric features: the case study of Sabocos Tarn, Pyrenees. Environ. Sci. Pollut. Res. 22, 231-247. doi: 10.1007/s11356-014-3310-0

Scala, D. J., and Kerkhoff, L. J. (2000). Horizontal heterogeneity of denitrifying bacterial communities in marine sediments by terminal restriction fragment length polymorphism analysis. Appl. Environ. Microbiol. 66, 1980-1986. doi: 10.1128/AEM.66.5.1980-1986.2000

Shibata, H., Branquinho, C., McDowell, W. H., Mitchell, M. J., Monteith, D. T., Tang, J., et al. (2015). Consequence of altered nitrogen cycles in the coupled human and ecological system under changing climate: the need for long-term and site-based research. Ambio 44, 178-193. doi: 10.1007/s13280-014-0545-4

Sinsabaugh, R. L., and Follstad-Shah, J. J. (2012). Ecoenzymatic stoichiometry and ecological theory. Annu. Rev. Ecol. Evol. Syst. 43, 313-343. doi: 10.1146/ annurev-ecolsys-110411-160245

Sinsabaugh, R. L., Hill, B. H., and Follstad-Shah, J. J. (2009). Ecoenzymatic stoichiometry of microbial organic nutrient acquisition in soil and sediment. Nature 462, 795-798. doi: 10.1038/nature08632
Steffen, W., Richardson, K., Rockström, J., Cornell, S. E., Fetzer, I., Bennett, E. M., et al. (2015). Planetary boundaries: guiding human development on a changing planet. Science 347:1259855. doi: 10.1126/science. 1259855

Tabatabai, M. A. (1982). "Soil enzymes," in Methods of Soil Analysis, eds R. H. Miller and D. R. Keeney (Madison, WI: American Society of Agronomy), 903-947.

Tatti, E., Goyer, C., Burton, D. L., Wertz, S., Zebarth, B. J., Chantigny, M., et al. (2015). Tillage management and seasonal effects on denitrifier community abundance, gene expression and structure over winter. Microb. Ecol. 70, 795-808. doi: 10.1007/s00248-015-0591-x

Throbäck, I. N., Enwall, K., Jarvis, A., and Hallin, S. (2004). Reassessing PCR primers targeting nirS, nirK and nos $Z$ genes for community surveys of denitrifying bacteria with DGGE. FEMS Microbiol. Ecol. 49, 401-417. doi: 10. 1016/j.femsec.2004.04.01

Tiberti, R., Metta, S., Austoni, M., Callieri, C., Morabito, G., Marchetto, A., et al. (2013). Ecological dynamics of two remote Alpine lakes during ice-free season. J. Limnol. 72, 401-416. doi: 10.4081/jlimnol.2013.e33

Tortosa, G., Correa, D., Sánchez-Raya, A. J., Delgado, A., Sánchez-Monedero, M. A., and Bedmar, E. J. (2011). Effects of nitrate contamination and seasonal variation on the denitrification and greenhouse gas production in La Rocina Stream (Doñana National Park. SW Spain). Ecol. Eng. 37, 539-548. doi: 10.1016/ j.ecoleng.2010.06.029

van Spanning, R. J., Richardson, D. J., and Ferguson, S. J. (2007). "Introduction to the biochemistry and molecular biology of denitrification," in Biology of the Nitrogen Cycle, eds H. Bothe, S. Ferguson, and W. E. Newton (Amsterdam: Elsevier), 382-395.

Velasco-Ayuso, S., Sánchez-Medina, J. M., Guénon, R., and Carrillo, P. (2017). Ecoenzyme activity ratios reveal interactive effects of nutrient inputs and UVR in a Mediterranean high-mountain lake. Biogeochemistry 132, 71-85. doi: 10. 1007/s10533-016-0288-3

Vila-Costa, M., Bartrons, M., Catalan, J., and Casamayor, E. O. (2014). Nitrogen-cycling genes in epilithic biofilms of oligotrophic high-altitude lakes (Central Pyrenees, Spain). Microb. Ecol. 68, 60-69. doi: 10.1007/s00248-0140417-2

Villar-Argaiz, M., Medina-Sánchez, J. M., Cruz-Pizarro, L., and Carrillo, P. (2001). Inter- and intra-annual variability in the phytoplankton community of a high mountain lake: the influence of external (atmospheric) and internal (recycled) sources of phosphorus. Freshw. Biol. 46, 1017-1034. doi: 10.1046/j.1365-2427. 2001.00734.x

Wenk, C., Blees, J., Zopfi, J., and Veronesi, M. (2013). Anaerobic ammonium oxidation (anammox) bacteria and sulfide-dependent denitrifiers coexist in the water column of a meromictic south-alpine lake. Limnol. Oceanogr. 58, 1-12. doi: 10.4319/lo.2013.58.1.0001

Williamson, C. E., Saros, J. E., and Schindler, D. W. (2009). Sentinels of change. Science 323, 887-888. doi: 10.1126/science.1169443

Yoshinari, T., and Knowles, R. (1976). Acetylene inhibition of nitrous oxide reduction by denitrifying bacteria. Biochem. Biophys. Res. Commun. 69, 705-710. doi: 10.1016/0006-291X(76)90932-3

Zumft, W. G. (1997). Cell biology and molecular basis of denitrification. Microbiol. Mol. Biol. Rev. 61, 533-616.

Conflict of Interest Statement: The authors declare that the research was conducted in the absence of any commercial or financial relationships that could be construed as a potential conflict of interest.

Copyright (C) 2017 Castellano-Hinojosa, Correa-Galeote, Carrillo, Bedmar and Medina-Sánchez. This is an open-access article distributed under the terms of the Creative Commons Attribution License (CC BY). The use, distribution or reproduction in other forums is permitted, provided the original author(s) or licensor are credited and that the original publication in this journal is cited, in accordance with accepted academic practice. No use, distribution or reproduction is permitted which does not comply with these terms. 